\section{Pacific Northwest \\ National Laboratory}

Operated by Battelle for the

U.S. Department of Energy

\title{
Upper Basalt-Confined Aquifer System in the Southern Hanford Site
}

P. Thorne

\section{RECEIVED FEB 17 1999 OSTI}

December 1998

Prepared for the U.S. Department of Energy under Contract DE-AC06-76RLO 1830 


\title{
DISCLAIMER
}

This report was prepared as an account of work sponsored by an agency of the United States Government. Reference herein to any specific commercial product, process, or service by trade name, trademark, manufacturer, or otherwise does not necessarily constitute or imply its endorsement, recommendation, or favoring by the United States Government or any agency thereof, or Battelle Memorial Institute.

\author{
PACIFIC NORTHWEST NATIONAL LABORATORY \\ operated by \\ BATTELLE \\ for the \\ UNITED STATES DEPARTMENT OF ENERGY \\ under Contract DE-AC06-76RLO 1830 \\ Printed in the United States of America \\ Available to DOE and DOE contractors from the \\ Office of Scientific and Technical Information, P.O. Box 62, Oak Ridge, TN 37831; \\ prices available from (615) $576-8401$. \\ Available to the public from the National Technical Information Service, \\ U.S. Department of Commerce, 5285 Port Royal Rd, Springfield, VA 22161
}




\section{DISCLAIMER}

Portions of this document may be illegible in electronic image products. Images are produced from the best available original document. 


\section{Upper Basalt-Confined Aquifer System in the Southern Hanford Site}

P. Thorne

December 1998

Prepared for

the U.S. Department of Energy

under Contract DE-AC06-76RLO 1830

Pacific Northwest National Laboratory

Richland, Washington 99352 



\section{Summary}

The 1990 DOE Tiger Team Finding GW/CF-2 02 found that the hydrogeologic regime at the Hanford Site was inadequately characterized. This finding also identified the need for completing a study of the confined aquifer in the central and southern portions of the Hanford Site. The southern portion of the site is of particular interest because hydraulic-head patterns in the upper basalt-confined aquifer system indicate that groundwater from the Hanford central plateau area, where contaminants have been found in the aquifer, flows southeast toward the southern site boundary. This results in a potential for offsite migration of contaminants through the upper basalt-confined aquifer system.

Based on the review presented in this report, available hydrogeologic characterization information for the upper basalt-confined aquifer system in this area is considered adequate to close the action item. Recently drilled offsite wells have provided additional information on the structure of the aquifer system in and near the southern part of the Hanford Site. Information on hydraulic properties, hydrochemistry, hydraulic heads and flow directions for the upper basalt-confined aquifer system has been re-examined and compiled in recent reports including Spane and Raymond (1993), Spane and Vermeul (1994), and Spane and Webber (1995).

No contaminants from Hanford Site sources have been identified in the basalt-confined aquifers in the southern part of the Hanford Site. Available hydrogeologic data, however, indicate that there is a potential for contaminated groundwater found in the upper basalt-confined aquifer in the central plateau area to eventually cross the southern Hanford Site boundary. The direction of groundwater flow in the southern part of the Hanford Site is southeast, toward discharge areas associated with the Columbia River. Based on estimates of aquifer hydraulic properties and hydraulic gradient, groundwater within the upper basalt-confined aquifers moves at about $3 \mathrm{~m} / \mathrm{y}$, and it would take more than 8,000 years for contaminants to reach the southern site boundary under current flow conditions. Isotopic age-dating of groundwater indicates similarly long travel times.

Eventually, groundwater in the upper basalt-confined aquifers must either move upward into the unconfined aquifer and discharge to the Columbia River or move parallel to the river across the southern site boundary. Therefore, the potential for contaminated groundwater to cross the southern boundary depends on the degree of intercommunication between the upper basalt-confined aquifers and the unconfined aquifer in this area. If intercommunication is limited, then groundwater is more likely to cross the boundary. Offsite water and land use immediately south of the Hanford Site affects the pattern of groundwater flow in this area. For example, recharge from imported irrigation water may increase the hydraulic head south of the Site and reduce the potential for groundwater to move across the southern boundary. In contrast, pumping of groundwater from the upper basalt-confined aquifer south of the Hanford Site would have the opposite effect on hydraulic head conditions. Monitoring of water quality and hydraulic head conditions in the upper basalt-confined aquifer system is conducted to verify the current understanding of the flow system and ensure that contaminants do not migrate offsite through this pathway. 



\section{Contents}

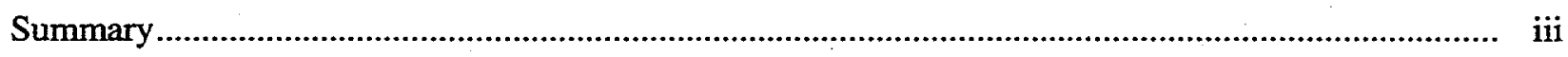

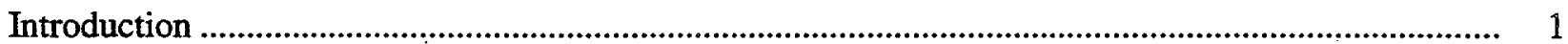

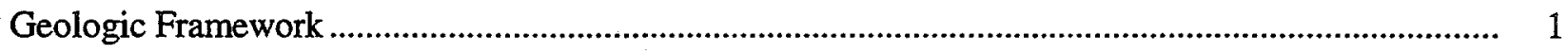

Upper Basalt-Confined Aquifer Wells in the Southern Hanford Site …........................................... 5

Groundwater Flow Direction and Aquifer Intercommunication ..................................................... 5

Factors Affecting the Potential for Migration of Contaminants Across the Southern Boundary ............. 8

Recharge from the Rattlesnake Hills ....................................................................................... 10

Interaction with the Yakima River ......................................................................................... 10

Discharge to the Unconfined Aquifer Near the Columbia River ................................................ 10

Impact of Offsite Land Use and Groundwater Use ................................................................ 10

Aquifer Hydraulic Properties................................................................................................ 11

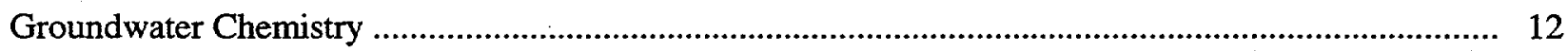

Distribution of Contaminants from Hanford Site Sources............................................................... 14

Potential for Contaminant Migration Across the Southern Hanford Site Boundary ……....................... 15

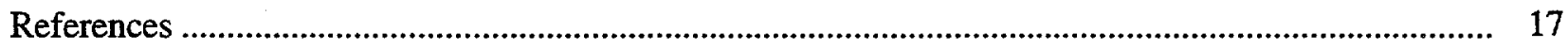




\section{Figures}

1 Basalt-Confined Aquifer Wells in the Southern Part of the

Hanford Site and Cross Section Locations ............................................................................. 2

2 West to East Cross Section Near the Southern Site Boundary ................................................... 3

3 North to South Cross Section Near the Columbia River.......................................................... 4

4 Isopach Map of the Rattlesnake Ridge Interbed on the Hanford Site ........................................ 6

5. Potentiometric Map of the Upper Basalt-Confined Aquifer System - March 1993...................... 7

6 Comparison of Observed Hydraulic Heads for the Upper Basalt-Confined and

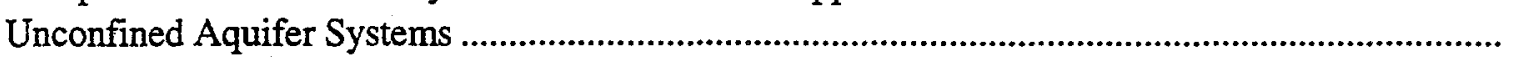

7 Hydrochemical Facies (Stiff Diagrams) Map for Groundwater Within the Upper Basalt-Confined Aquifer System

\section{Tables}

1 Transmissivity Measurements for the Upper Basalt-Confined Aquifer in the Southern Part of the Hanford Site

2 Nitrate, Tritium and Iodine-129 Concentrations Measured in Southern Hanford Site Wells During 1990 to 1996 


\section{Introduction}

This report summarizes available information regarding the upper basalt-confined aquifer system in the southern portion of the Hanford Site (south of the Washington Public Power Supply System). The objective of this review is to determine whether currently available information is sufficient to close an action item related to the 1990 DOE Tiger Team Finding GW/CF-2 02, which found inadequate characterization of the hydrogeologic regime. The action item states "complete confined aquifer study of the central and southern portions of the Hanford Site." The southern portion of the site is of particular interest because hydraulic-head patterns in the upper basalt-confined aquifer system indicate that groundwater from the central plateau area, where contaminants have been found in the aquifer, flows to the southeast.

\section{Geologic Framework}

Basalt-confined aquifers beneath the Hanford Site are primarily located at the contacts of basalt flows of the Columbia River Basalt Group. The most recent, laterally extensive sequence of basalt flows underlying the Hanford Site is the Elephant Mountain Member of the Saddle Mountains Basalt Formation. Locally overlying the Elephant Mountain Member is the Ice Harbor Member, which is found only in the southern part of the Site (DOE 1988). The Ice Harbor basalt crops out in the "Yakima Horn" area (Figure 1) across the Yakima River from the southern boundary of the Hanford Site (Reidel and Fecht 1994).

Inter-layered between various basalt flows are sedimentary interbeds collectively called the Ellensburg Formation. The Ellensburg Formation includes fluvial and lacustrine sediments consisting of mud, sand, and gravel which, along with porous basalt flow-tops and flow-bottoms, form basalt-confined aquifers that extend across the Pasco Basin (DOE1988).

The upper basalt-confined aquifer system in the southern Hanford Site is composed of the Levey and Rattlesnake Ridge interbeds and permeable basalt interflow contact zones within the Elephant Mountain and Ice Harbor Members. Over most of the Hanford Site, the Rattlesnake Ridge interbed forms the uppermost, laterally extensive basalt-confined aquifer (Spane and Webber 1995). However, in the southern part of the Hanford Site, the Levey Interbed is confined below the Ice Harbor Member and forms the uppermost basalt-confined aquifer in this region. Other interflow zones (i.e., contacts between individual basalt flows) within the Ice Harbor or Elephant Mountain Members may also be relatively permeable.

Figure 1 shows the approximate extent of the Levey interbed and identifies wells in the southern part of the Hanford Site where this interbed occurs. Figure 2 shows a west to east cross section near the southern boundary of the Site that illustrates the relationship of the various hydrogeologic units. Figure 3 shows a north to south cross section near the Columbia River. Locations of the cross sections are 


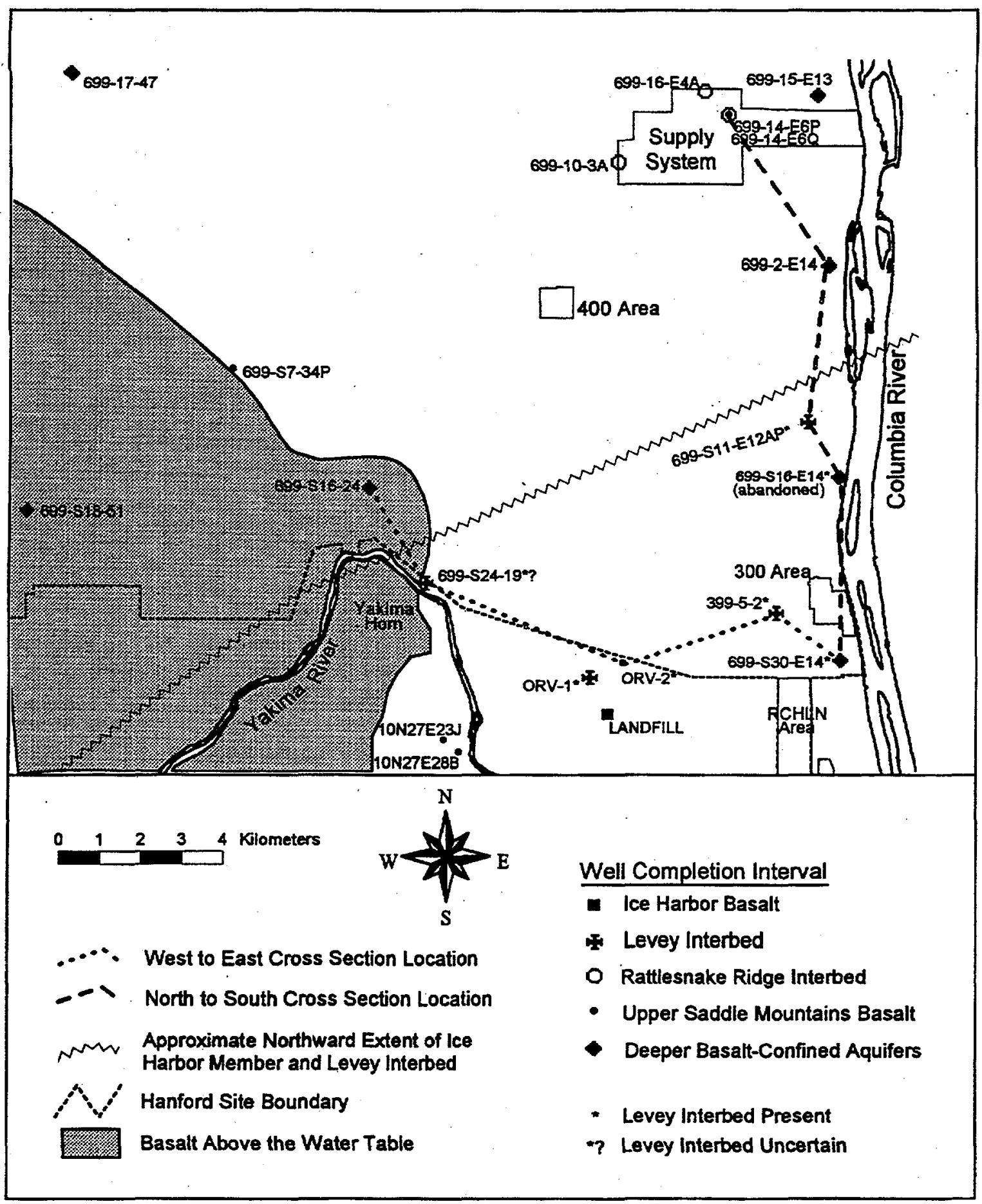

Figure 1. Basalt-Confined Aquifer Wells in the Southern Part of the Hanford Site and Cross Section Locations 


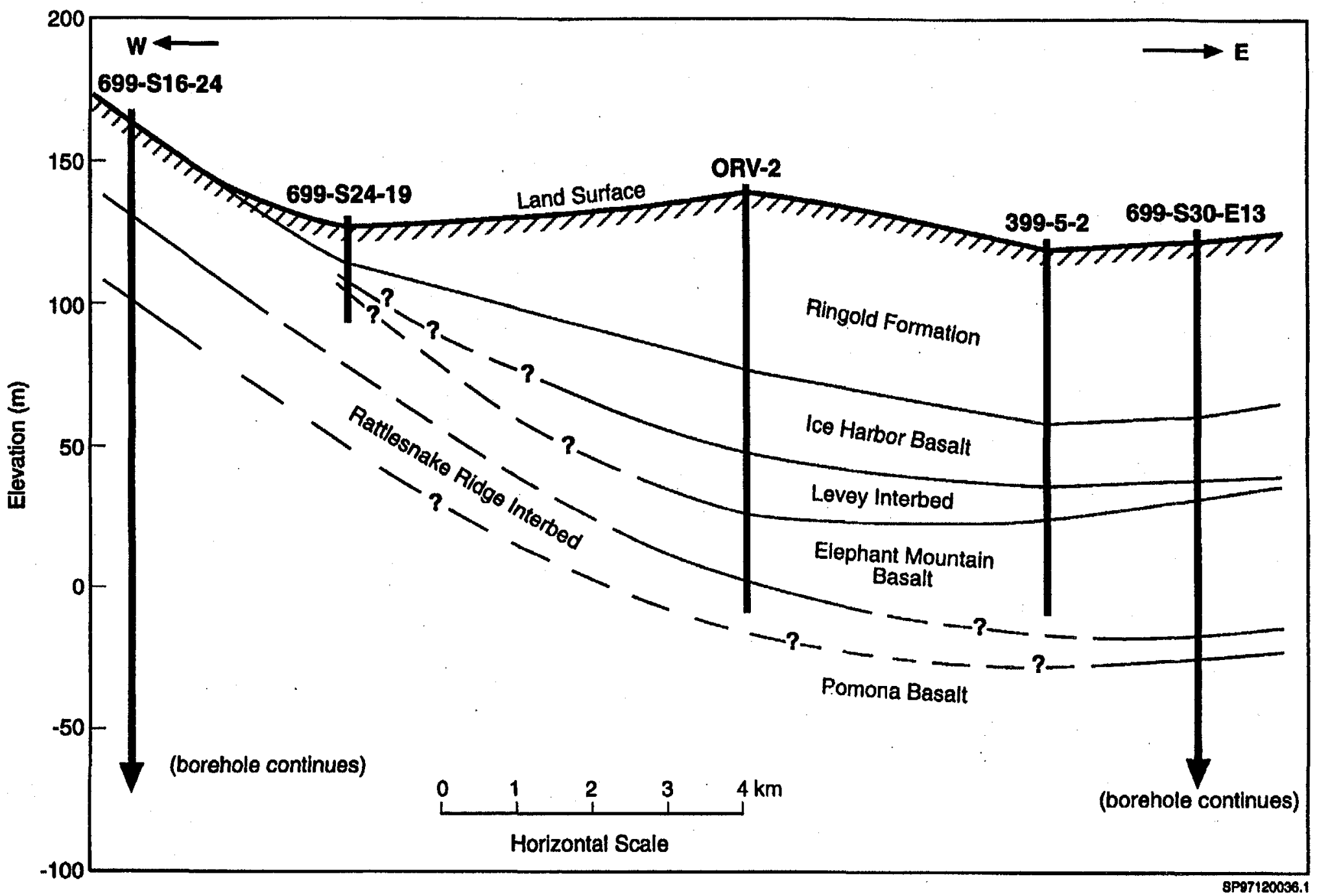

Figure 2. West to East Cross Section Near the Southern Site Boundary (see Figure 1 for location) 


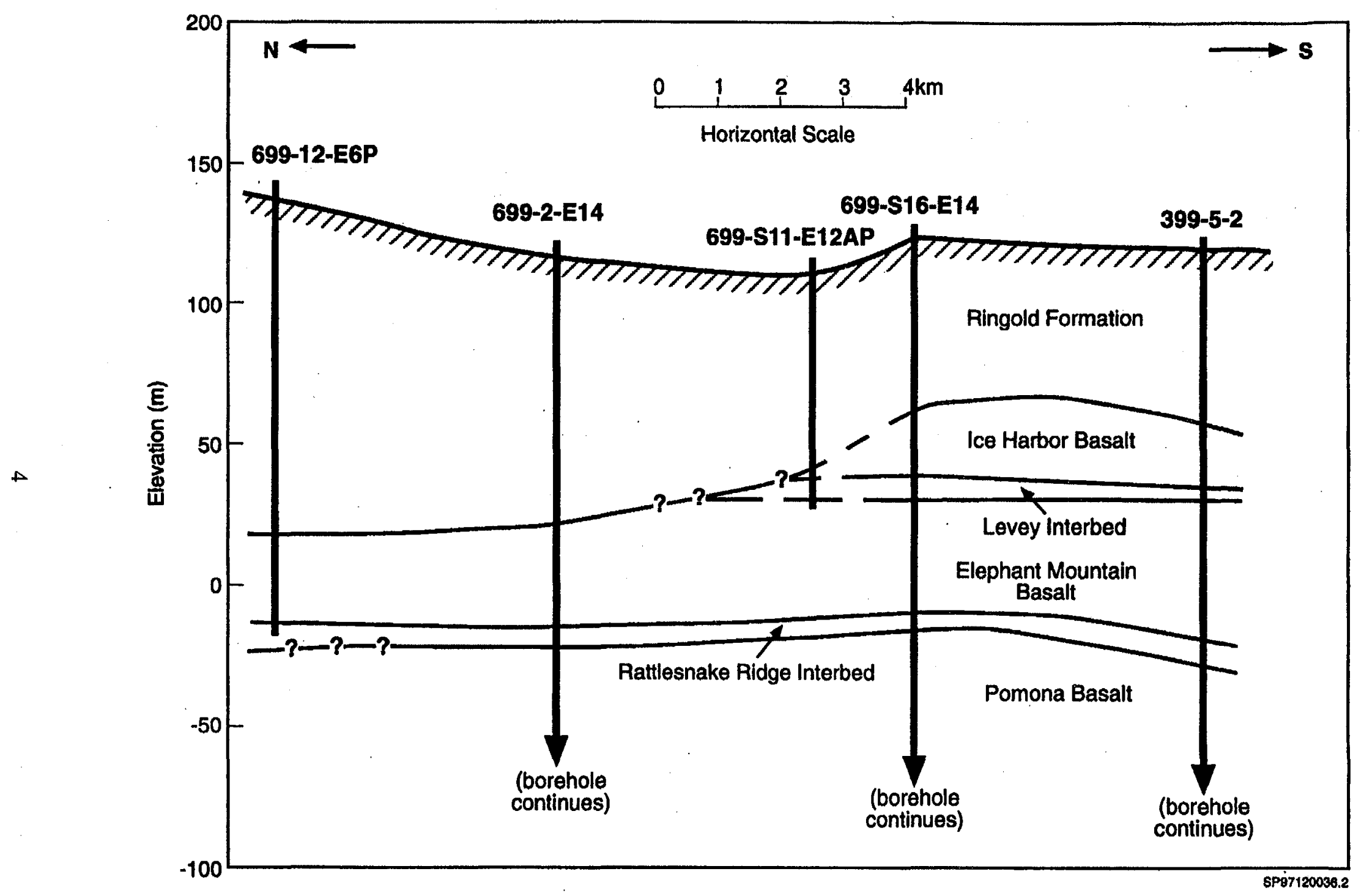

Figure 3. North to South Cross Section Near the Columbia River (see Figure 1 for location) 
indicated on Figure 1. Geologic information for offsite wells was adapted from Liikala (1994). More information on the geologic framework of the overall basalt-confined aquifer system is available in DOE (1988), Spane and Vermeul (1994), and Spane and Webber (1995).

In the southern part of the Hanford Site, the Rattlesnake Ridge interbed varies in thickness from 0 to about $25 \mathrm{~m}$. Figure 4 shows an isopach map of the Rattlesnake Ridge interbed. As shown, the interbed thins to the south and is absent along the eastern and southwestern boundaries of the Hanford Site. In the southern part of the Hanford Site, the Rattlesnake Ridge interbed is characteristically composed of a tuffaceous sandstone to tuffaceous siltstone (Spane and Webber 1995). The Levey interbed is also composed of tuffaceous sandstone and/or clay, and a maximum thickness of about $20 \mathrm{~m}$ has been observed at wells ORV-2 and 699-S51-2, located south of the area shown in Figure 1.

\section{Upper Basalt-Confined Aquifer Wells in the Southern Hanford Site}

Wells completed in the upper basalt-confined aquifer system in the southern part of the Hanford Site and in the surrounding offsite area are shown in Figure 1. Some wells are completed in the Rattlesnake Ridge or Levey interbeds and others are completed in deeper basalt-confined aquifers, primarily the Mabton interbed. A few wells, such as the well labeled LANDFILL, are completed within the Ice Harbor basalt. Offsite wells labeled LANDFILL, ORV-1, and ORV-2 are water-supply wells for the City of Richland landfill and off-road vehicle park, respectively. The landfill well is completed within the Ice Harbor Basalt and, based on projections of the elevation of the Levey interbed in nearby wells, appears to end just at the top of the Levey interbed. ORV-1 is completed across the Levey interbed. ORV-2 is completed in the lower part of the Levey interbed, through the Elephant Mountain Basalt, and into the Rattlesnake Ridge interbed. These wells potentially can be used for monitoring groundwater quality within the upper basalt-confined aquifer. Well 699-S24-19 was renovated during 1996 to isolate the unconfined aquifer from the underlying basalt-confined aquifer. The well was previously open to both intervals, although they had been temporarily isolated by placing a packer in the well.

\section{Groundwater Flow Direction and Aquifer Intercommunication}

Regional groundwater flow in the Pasco Basin is from areas of higher hydraulic head at the uplifted margins of the basin toward the Columbia River, which is the regional discharge area for both the unconfined and confined aquifer systems (Whiteman 1986; DOE 1988). Figure 5 shows a map of the measured and inferred hydraulic head distribution for the upper basalt-confined aquifer beneath the Hanford Site.

In the southern part of the Site, groundwater in the basalt-confined aquifer system moves southeastward from the Rattlesnake Hills toward the Columbia River. Hydraulic heads increase on the eastern side of the Columbia River, across from the Hanford Site, limiting the potential for groundwater flow to the east. The elevated hydraulic heads east of the Columbia River have been associated with artificial 


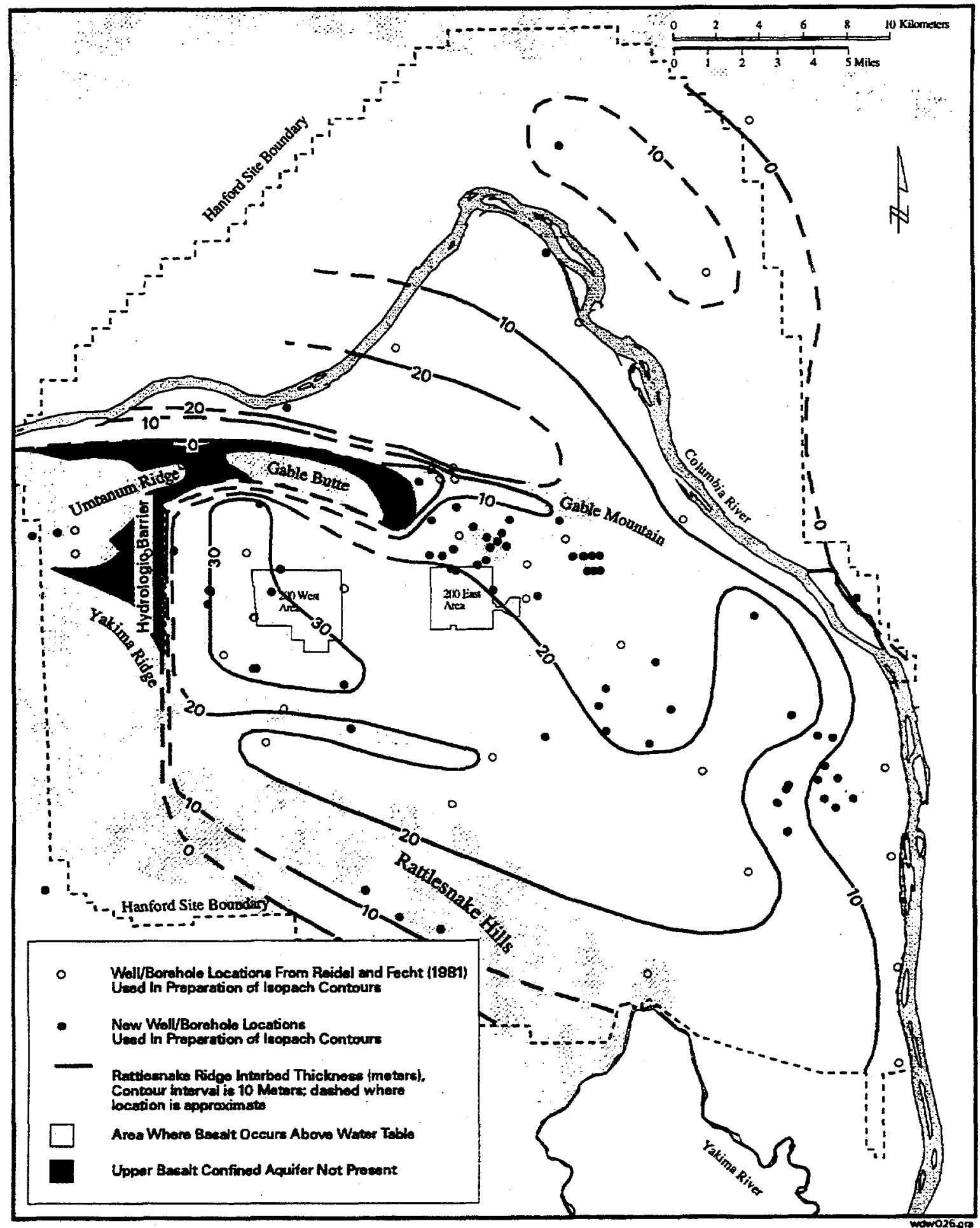

Figure 4. Isopach Map of the Rattlesnake Ridge Interbed on the Hanford Site (Spane and Webber 1995) 


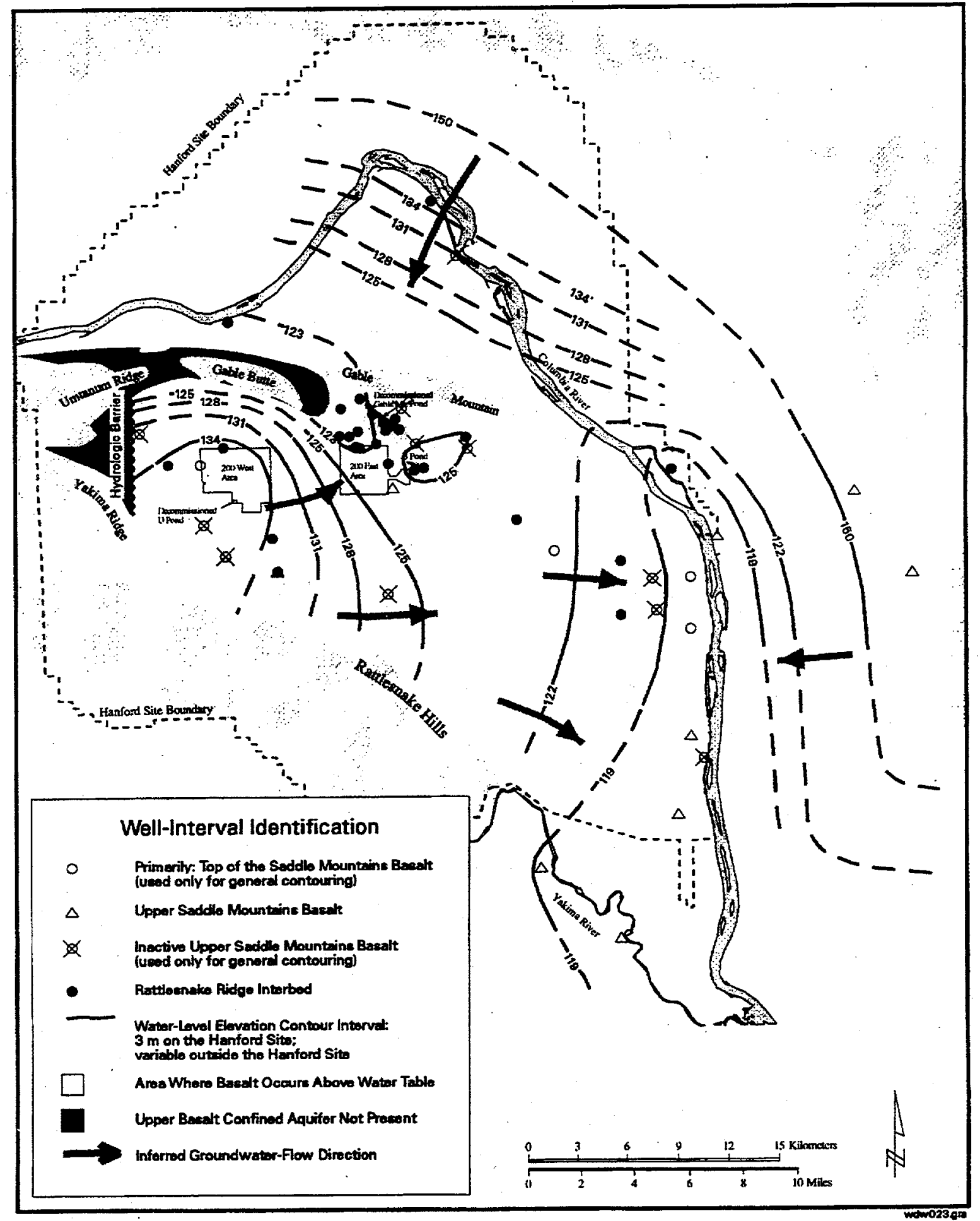

Figure 5. Potentiometric Map of the Upper Basalt-Confined Aquifer System - March 1993 (adapted from Spane and Raymond 1993) 
recharge from irrigation and canal leakage (Spane and Raymond 1993). Groundwater in the upper basaltconfined aquifer system flows obliquely to the southeast across the southern boundary of the Site. A potential therefore exists for contaminants in the basalt-confined aquifer to migrate across the southern boundary.

Vertical hydraulic gradients between the upper basalt-confined aquifer system and the unconfined aquifer system are generally downward near recharge areas such as the Rattlesnake Hills to the west and upward near discharge areas such as the Columbia River. The upward gradient in the eastern part of the Hanford Site results in a potential for upward discharge of groundwater to the unconfined aquifer system and eventually to the Columbia River (Spane and Webber 1995). Figure 6 shows measured head differences between the upper basalt-confined aquifer system and the overlying unconfined aquifer and delineates areas where the gradient is upward and downward. Upward discharge to the unconfined aquifer occurs at a low rate over the entire area with an upward gradient because of the low hydraulic conductivity of the confining units. However, faults or erosional channels that cut through the confining basalt layers may cause increased communication between the aquifer systems in some areas.

Figure 6 shows that an upward hydraulic gradient exists in the southern part of the Hanford Site. Increasing hydraulic heads with depth, indicating an upward hydraulic gradient, were also noted when well ORV-1 was drilled (Liikala 1994). The upward gradient makes it unlikely that any contaminants in the unconfined aquifer would migrate downward into the basalt-confined aquifer. However, pumping of

production wells located in the basalt-confined aquifer will act to lower hydraulic heads in this aquifer, and recharge of imported water will increase hydraulic heads in the unconfined aquifer, which may eventually result in a downward gradient.

\section{Factors Affecting the Potential for Migration of Contaminants Across the Southern Boundary}

Several factors are expected to influence groundwater flow conditions (and potential contaminant migration) along the southern boundary of the Hanford Site. These factors include:

- recharge from the Rattlesnake Hills region

- possible hydrologic communication/influence of the Yakima River

- discharge to the unconfined aquifer near the Columbia River

- offsite groundwater use activities. 


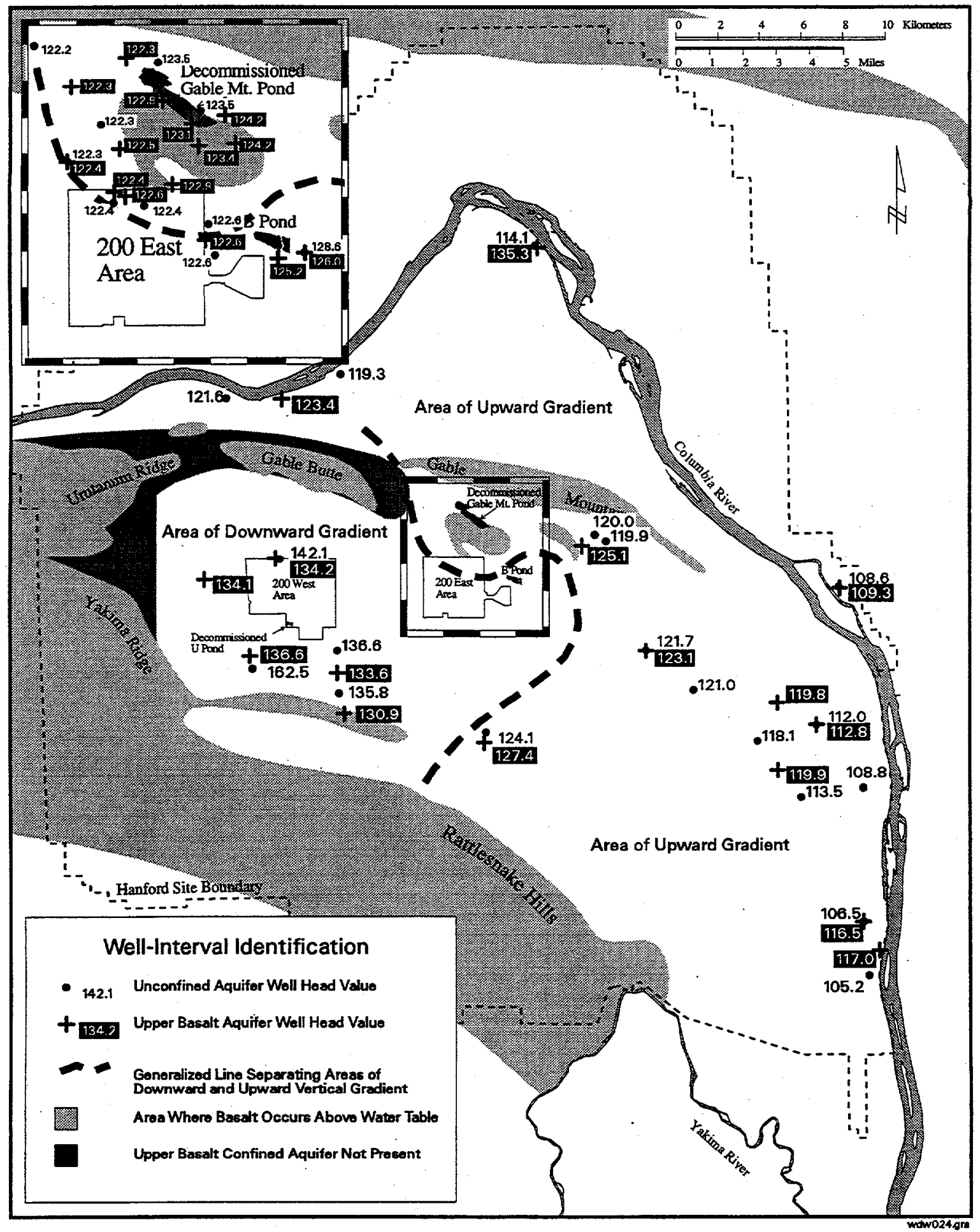

Figure 6. Comparison of Observed Hydraulic Heads for the Upper BasaltConfined and Unconfined Aquifer Systems 


\section{Recharge from the Rattlesnake Hills}

The Rattlesnake Hills, along the western boundary of the Hanford Site, is a recharge area for both the confined and unconfined aquifer systems beneath the Hanford Site (DOE 1988; Wurstner et al. 1995). Within the upper basalt-confined aquifer, this recharge results in a general west to east movement of groundwater across the central part of the Site towards the Columbia River. Wastewater disposal operations in the 200 Areas have locally altered this flow pattern and resulted in a southeast flow. The wastewater discharges have caused groundwater mounds in the unconfined aquifer and have also affected the upper basalt-confined aquifer in the vicinity of B Pond (see Figure 5). However, the mound is expected to dissipate as wastewater discharges are reduced (Hartman and Dresel 1997).

\section{Interaction with the Yakima River}

There is some evidence that the Yakima River may also recharge the upper basalt-confined aquifer (see the Groundwater Chemistry section below). The river is in contact with the basalt formation in the vicinity of the Yakima Horn. If recharge is occurring along the river, the potential for groundwater flow across the southern boundary of the Hanford Site is reduced because of the resulting north/northeastward gradient. To help define aquifer behavior in the vicinity of the Yakima River, river-stage monitoring has been conducted at a location just below Horn Rapids Dam. These data were compared to water levels measured in both the unconfined aquifer system and the basalt-confined aquifer system at nearby well 699-S24-19 (Thome et al. 1993). Water levels at this well did not show a direct response to changes in river stage. However, the water level of the unconfined aquifer interval did respond to the filling of a canal (the Horn Rapids Ditch) between the well and the river. It appears that the basalt-confined aquifer monitored at this well is not hydraulically connected to the Yakima River. It is not certain whether the basalt confined interval at this well is the Levey interbed or a different interflow zone (see Figure 2).

\section{Discharge to the Unconfined Aquifer Near the Columbia River}

The groundwater flow pattern in the upper basalt-confined aquifer system shows apparent discharge in the vicinity of the Columbia River along the southeastern boundary of the Hanford Site, south of the Supply System (Figure 5). Faults or erosional channels associated with the extension of the Gable Mountain-Gable Butte anticline may be present in this area. The upper basalt-confined aquifer is not in direct contact with the river in this area. If communication between the aquifers is limited and the amount of upward discharge is low, then it is more likely that groundwater in the upper basalt-confined aquifer will flow across the southern Site boundary as it moves toward a discharge area located farther south. High rates of upward discharge along the Columbia River adjacent to the Hanford Site would result in water being discharged before it flowed across the southern Site boundary. The actual amount of discharge from the upper basalt-confined aquifer in this area is not known and would be difficult to quantify.

\section{Impact of Offsite Land Use and Groundwater Use}

Offsite land use and groundwater use south of the Site boundary, in the area between the Yakima and Columbia rivers, also affect the pattern of groundwater flow in the upper basalt-confined aquifer. Liikala 
(1994) tabulates estimated irrigation water volumes applied to farmland in this area. The applied water is mostly (95\%) imported from the Columbia River. Most of the remainder is pumped from wells completed in the unconfined aquifer. The resulting recharge may contribute to a northward gradient that would reduce the potential for groundwater to move across the boundary. However, this recharge primarily affects hydraulic heads within the unconfined aquifer. The degree to which the upper basaltconfined aquifer is affected depends on the degree of hydraulic connection between these units, which is largely unknown. Pumping of production wells completed in the upper basalt-confined aquifer has the opposite effect. The wells labeled LANDFILL, ORV-1, and ORV-2 provide water for the City of Richland landfill and off-road vehicle park. Farther south and across the Yakima River, wells completed in the upper Saddle Mountains Basalt are pumped to supply water to the City of West Richland. Pumping these wells may create a depression in the potentiometric surface causing a more southward flow across the southern boundary of the Hanford Site.

\section{Aquifer Hydraulic Properties}

Aquifer hydraulic properties affect the migration of contaminants through the aquifer. Groundwater and contaminant velocity is proportional to both the aquifer transmissivity and the hydraulic gradient, and inversely proportional to the effective porosity. Hydraulic properties for various basalt-confined aquifers were studied extensively as part of the Basalt Waste Isolation Project investigations. These data are summarized in Gephart et al. (1979), Strait and Mercer (1987), and DOE (1988). Spane and Vermuel (1994) compiled available test results and data for the upper basalt-confined aquifer system and reanalyzed the data using recently developed diagnostic tools (i.e., pressure derivative analysis). A total of 35 tests was re-examined including 22 for the Rattlesnake Ridge interbed and 2 for the Levey interbed. The reanalysis generally resulted in calculated transmissivity values that were lower than the originally calculated transmissivity, with reanalysis results usually within a factor of two of the original values. Spane and Vermeul (1994) found that $90 \%$ of the transmissivity values for the upper basalt-confined aquifer were between 1 and $100 \mathrm{~m}^{2} / \mathrm{d}$, and $65 \%$ of the values were between 10 and $100 \mathrm{~m}^{2} / \mathrm{d}$. Values reported for aquifer tests at selected wells in the southern part of the Hanford Site are presented in Table 1.

Table 1. Transmissivity Measurements for the Upper Basalt-Confined Aquifer in the Southern Part of the Hanford Site (Spane and Vermeul 1994)

\begin{tabular}{|l|c|c|c|}
\hline \multicolumn{1}{|c|}{ Well } & Depth Interval $(\mathbf{m})$ & Formation & $\begin{array}{c}\text { Transmissivity } \\
\left(\mathbf{m}^{\mathbf{2}} / \mathbf{d}\right)\end{array}$ \\
\hline $399-5-2$ & $59.4-129.2$ & Composite & 1.9 \\
\hline $699-S 16-E 14$ & $83.8-104.5$ & Rattlesnake Ridge & 13 \\
\hline $699-S 16-E 14$ & $127.2-151.2$ & Levey & 14 \\
\hline $699-S 11-E 12 A$ & $70.1-79.1$ & Levey & 1.8 \\
\hline
\end{tabular}


Effective porosity of the upper basalt-confined aquifer is less well known but likely varies over a smaller range than the transmissivity. The effective porosity of the sedimentary interbeds is generally less than 0.2 (DOE 1988). Assuming an aquifer transmissivity of $15 \mathrm{~m}^{2} / \mathrm{d}$, a thickness of $20 \mathrm{~m}$, an effective porosity of 0.1 , and a average hydraulic gradient (from Figure 5) of 0.0005 , the groundwater velocity would be $1.4 \mathrm{~m} / \mathrm{y}$ in the upper basalt-confined aquifer in the southern part of the Hanford Site. This should be considered an approximation because of the uncertainty in the hydraulic properties. Similarly, Spane and Webber (1995) estimated a groundwater velocity of 0.7 to $2.9 \mathrm{~m} / \mathrm{y}$ based on an assumed effective porosity range of 0.1 to 0.3 . They also estimated groundwater velocity based on the C-14 age dating of groundwater from wells 699-17-47 and 699-S16-E14. The age difference was $9605 \mathrm{y}$, which implied a groundwater flow velocity of $2.2 \mathrm{~m} / \mathrm{y}$ between these wells.

\section{Groundwater Chemistry}

Groundwater chemistry and isotopic data are useful in understanding the history of groundwater within the aquifer and in identifying the spread of contaminants. To this end, basalt-confined aquifer wells are routinely sampled for chemical and radiological constituents. Results are presented annually in the Hanford Site Groundwater Monitoring Report (e.g., Hartman and Dresel 1997). Spane and Webber (1995) list recent chemical and radiological data for Hanford Site upper basalt-confined aquifer wells and have also compiled available information for stable environmental isotopes $\mathrm{H}-2, \mathrm{O}-18, \mathrm{~S}-34$, and $\mathrm{C}-13$ within the upper basalt-confined aquifers. They also provide information on natural and Hanfordproduced radioactive isotopes. Whiteman et al. (1994) provided information on the groundwater chemistry of the regional basalt-confined aquifer system.

As noted by Spane and Webber (1995), groundwater within the basalt-confined aquifers evolves from a $\mathrm{Ca}, \mathrm{Mg}-\mathrm{HCO}_{3}$ chemical water type to a $\mathrm{Na}$-dominated water type with increasing residence time in the aquifer. Stiff diagrams displayed in Figure 7 indicate the dominant cations present in samples from the upper basalt-confined aquifers. Samples from both the Levey and Rattlesnake Ridge interbeds in the southern part of the Hanford Site are of the Na-dominated type indicating relatively long residence times. In contrast, samples from wells in the Gable Mountain-200 East Area are CA, $\mathrm{Mg}-\mathrm{HCO}_{3}$ type indicating recent recharge to the aquifer in that area. Offsite wells that tap the upper Saddle Mountains Basalt aquifers across the Yakima River south of the Hanford Site are also of the $\mathrm{Ca}, \mathrm{Mg}-\mathrm{HCO}_{3}$ type indicating more recent recharge. Recharge in this area is unrelated to Hanford Site activities.

The isotopic composition of groundwater from the basalt-confined aquifers beneath the Hanford Site also provides information on the origin and evolution of the groundwater. Samples from the aquifer are generally of lighter isotopic composition with respect to $\mathrm{H}-2$ and O-18 than water found in the Columbia or Yakima rivers (Spane and Webber 1995). As reported by Graham (1983), the isotopic content is similar to local precipitation that occurs during the winter on the Rattlesnake Hills. Therefore, it is likely that the water in the aquifer was recharged under similar conditions and perhaps in the same area in the past. 


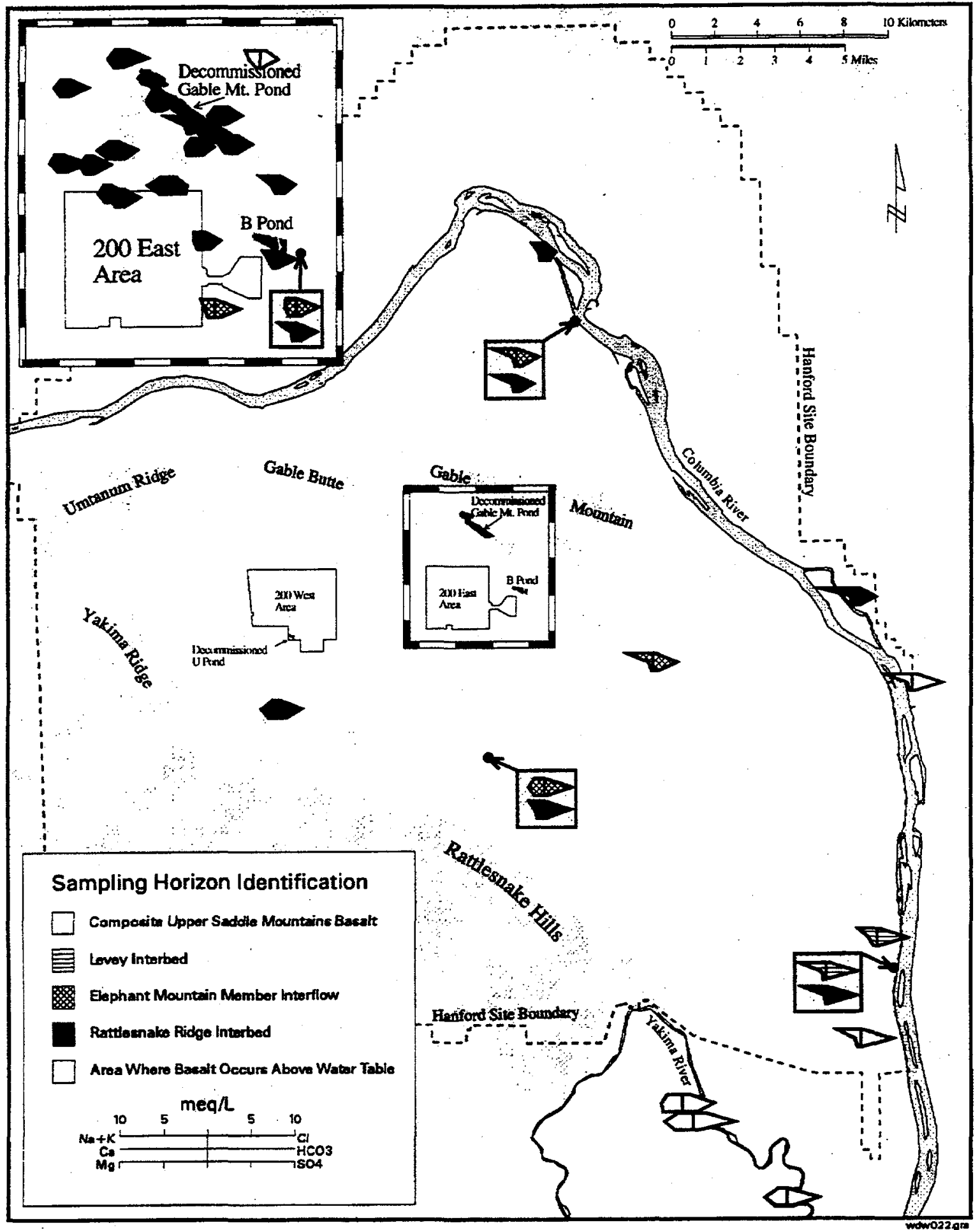

Figure 7. Hydrochemical Facies (Stiff Diagrams) Map for Groundwater Within the Upper Basalt-Confined Aquifer System (Spane and Webber 1995) 
Spane and Webber (1995) showed that although the isotopic composition (H-2 and O-18) of groundwater from the upper basalt-confined aquifers beneath the southern part of the Hanford Site was distinct from the composition of Yakima River water, groundwater from the upper Saddle Mountains Basalt south of the Yakima River (wells 10N27E28B, 09N28E05C, and 10N27E23J) was similar to the composition of Yakima River water. This indicates possible recharge from the river to the basaltconfined aquifer in the area adjacent to the river. Recharge of Yakima River water could also be occurring because of irrigation in this area. Wells in the southern part of the Hanford Site appear to be influenced more by recharge from the Rattlesnake Hills.

\section{Distribution of Contaminants from Hanford Site Sources}

Contaminant plumes originating in the 200 Areas, particularly tritium, nitrate, and iodine-129, are widespread in the unconfined aquifer system at the Hanford Site. These plumes extend southward to approximately the southern part of the 300 Area (Hartman and Dresel 1997). Nitrate from offsite sources is also found immediately south of the Hanford Site. This plume extends across the site boundary (Hartman and Dresel 1997).

Within the upper basalt-confined aquifer, contamination from Hanford sources has been found only in the vicinity of the 200 Areas, particularly in the area between the 200 East Area and Gable Mountain (IGW 1987; DOE 1988; Spane and Webber 1995). Recent measurements of tritium, $\mathrm{NO}_{3}$, and iodine-129 for wells in the southern part of the Hanford Site are listed in Table 2. Tritium concentrations in the basalt-confined aquifers are generally lower than the concentrations found in precipitation or water from the Yakima or Columbia rivers because these waters have been affected by tritium from testing of nuclear weapons. As reported by Spane and Webber (1995), tritium is slightly elevated, similar to Yakima River water, in wells south of the Yakima River. This is consistent with possible recharge of river water, which is also supported by stable isotope data. Iodine- 129 concentrations in older groundwater found in the basalt-confined aquifers are also generally lower than concentrations found in precipitation and surface waters because of atmospheric releases of iodine- 129 from nuclear fuel processing operations. IWG (1987) provides a compilation of iodine-129 data for the Hanford Site and discusses likely sources of iodine-129 found in the basalt-confined aquifer system. In the southern part of the Hanford Site, iodine129 concentrations are generally at expected low background values or are explained by recent recharge of surface water. Iodine-129 has been found at well 699-S16-24 in the Mabton interbed, a deeper basaltconfined aquifer, at concentrations comparable to values in surface water and precipitation. IGW (1987) concluded that the source was probably not the same as iodine-129 found in the Hanford 200 areas because tritium/iodine-129 and technetium-99/iodine-129 ratios for the well samples are much lower. Tritium and technetium- 99 would also be expected in elevated concentrations if the source were associated with the 200 Area releases. 
Table 2. Nitrate, Tritium and Iodine- 129 Concentrations Measured in Southern Hanford Site Wells During 1990 to 1996

\begin{tabular}{|l|c|l|c|}
\hline \multicolumn{1}{|c|}{ Well Name } & Date & \multicolumn{2}{c|}{ Nitrate (NO3) } \\
\hline $399-5-2$ & $9 / 1 / 94$ & 0.20 & $\mathrm{mg} / \mathrm{L}$ \\
\hline $399-5-2$ & $4 / 6 / 95$ & 0.06 & $\mathrm{mg} / \mathrm{L}$ \\
\hline 699-S11-E12AP & $1 / 19 / 95$ & 0.02 & $\mathrm{mg} / \mathrm{L}$ \\
\hline 699-S11-E12AP & $1 / 23 / 96$ & 2.30 & $\mathrm{mg} / \mathrm{L}$ \\
\hline 699-S11-E12AP & $7 / 23 / 96$ & 0.066 & $\mathrm{mg} / \mathrm{L}$ \\
\hline 699-S24-19P & $9 / 5 / 96$ & 0.018 & $\mathrm{mg} / \mathrm{L}$ \\
\hline 699-S24-19Q & $9 / 5 / 96$ & 0.056 & $\mathrm{mg} / \mathrm{L}$ \\
\hline Well Name & Date & \multicolumn{2}{|c|}{ Iodine-129 } \\
\hline $399-5-2$ & $9 / 1 / 94$ & -0.28 & $\mathrm{pCi} / \mathrm{L}$ \\
\hline $699-\mathrm{S} 11-\mathrm{E} 12 \mathrm{AP}$ & $6 / 22 / 93$ & 0.308 & $\mathrm{pCi} / \mathrm{L}$ \\
\hline Well Name & Date & \multicolumn{2}{|c|}{ Tritium } \\
\hline $399-5-2$ & $9 / 1 / 94$ & -0.319 & $\mathrm{pCi} / \mathrm{L}$ \\
\hline $399-5-2$ & $4 / 6 / 95$ & -1.89 & $\mathrm{pCi} / \mathrm{L}$ \\
\hline $699-\mathrm{S} 11-\mathrm{E} 12 \mathrm{AP}$ & $6 / 22 / 93$ & 0.639 & $\mathrm{pCi} / \mathrm{L}$ \\
\hline $699-\mathrm{S} 11-\mathrm{A} 12 \mathrm{AP}$ & $8 / 12 / 94$ & 0.287 & $\mathrm{pCi} / \mathrm{L}$ \\
\hline $699-\mathrm{S} 11-\mathrm{E} 12 \mathrm{AP}$ & $1 / 19 / 95$ & -3.43 & $\mathrm{pCi} / \mathrm{L}$ \\
\hline $699-\mathrm{S} 11-\mathrm{E} 12 \mathrm{AP}$ & $7 / 23 / 96$ & -0.662 & $\mathrm{pCi} / \mathrm{L}$ \\
\hline $699-\mathrm{S} 24-19 \mathrm{P}$ & $9 / 5 / 96$ & 14.1 & $\mathrm{pCi} / \mathrm{L}$ \\
\hline $699-\mathrm{S} 24-19 \mathrm{Q}$ & $9 / 5 / 96$ & 12.0 & $\mathrm{pCi} / \mathrm{L}$ \\
\hline
\end{tabular}

\section{Potential for Contaminant Migration Across the Southern Hanford Site Boundary}

Currently available hydrogeologic data indicate that contaminated groundwater found in the upper basalt-confined aquifer in the central plateau area may eventually cross the southern Hanford Site boundary. However, there are two hydrologic phenomena that reduce the potential for this to occur. These are: 1) groundwater discharge from the upper basalt-confined aquifer system to the unconfined aquifer system in the vicinity of Gable Mountain, and 2) the possible discharge of groundwater to the unconfined aquifer, and eventually to the Columbia River, along the southeastern boundary of the Hanford Site.

As shown in Figure 5, an area of relatively low potentiometric head occurs in the region between Gable Butte and Gable Mountain, north of the 200 East Area (Spane and Raymond 1993). Both hydraulic head data and hydrochemistry data indicate that this is an area of increased hydraulic communication between the upper basalt-confined aquifer system and the unconfined aquifer system (Graham et al. 1984; Jensen 1987; Early et al. 1988; DOE 1988). Groundwater in the upper basalt-confined aquifer flows 
toward this discharge area from both the north and the south. Under the hydrologic conditions shown in Figure 5, a groundwater divide exists in the vicinity of the 200 East Area with flow northward on the north side of the divide and flow southward on the south side of the divide. Therefore, contaminated groundwater in the aquifer north of the divide is not expected to flow toward the southern part of the Site or cross the southern Site boundary. As wastewater discharge and hydraulic head in the unconfined aquifer are reduced, the amount of groundwater discharge from the upper basalt-confined aquifer to the unconfined aquifer is expected to increase in the area near Gable Mountain. This may shift the location of the groundwater divide to the south and further reduce the potential for flow of contaminants to the southeast.

Groundwater that moves to the southeast across the Hanford Site through the upper basalt-confined aquifer converges in the vicinity of the Columbia River with flow from the agricultural area east of the river. It is unlikely that groundwater will move eastward across the river because of elevated hydraulic heads east of the river. The Columbia River delineates an apparent discharge area for the upper basaltconfined aquifer along the southeastern boundary of the site (Spane and Webber 1995). However, the degree of intercommunication between the aquifer systems and the actual amount of discharge is unknown. If the discharge is limited, then groundwater in the upper basalt-confined aquifer is likely to flow downgradient within the upper basalt-confined aquifer and cross the southern Hanford Site boundary.

If groundwater in the upper basalt-confined aquifer system does move across the southern boundary of the Hanford Site, long travel times would be required for contaminants from the central plateau area to reach the southern boundary. The most direct distance is about $26 \mathrm{~km}$. Assuming the upper groundwater velocity estimate of $2.9 \mathrm{~m} / \mathrm{y}$, a travel time of more than $8,000 \mathrm{y}$ is indicated. However, because there is a potential for contaminated groundwater in the upper basalt-confined aquifer system to eventually flow offsite through this pathway, wells in this aquifer are monitored to track contaminant movement and changes in hydraulic head conditions. As discussed in the section on hydraulic heads, offsite land use and groundwater use south of the Hanford Site boundary may affect the future pattern of groundwater flow and flow velocities in the upper basalt-confined aquifer. Wastewater discharge practices and potential future irrigation of portions of the Hanford Site may also have an effect on flow patterns. Therefore, these activities may impact the potential for offsite migration of contaminants through the aquifer. Offsite wells near the southern boundary of the site, such as ORV2, may serve as additional monitoring points. 


\section{References}

DOE (U.S. Department of Energy). 1988. Consultation Draft, Site Characterization Plan, Reference Repository Location, Hanford Site, Washington. DOE/RW-0164, Vol. 1 and 2, U.S. Department of Energy, Richland, Washington.

Early, T. O., S. H. Hall, and V. G. Johnson. 1988. "Tritium, Carbon-14, and Iodine-129 as Indicators for Localized Vertical Recharge Along an Anticline in the Columbia River Basalts Using a Decay-Corrected Mixing Model" in Proceedings of the Ground Water Geochemistry Conference, February 16-18, 1988, Denver, Colorado, pp. 597-620. National Water Well Association, Dublin, Ohio.

Gephart, R. E., R. C. Arnett, R. G. Baca, L. S. Leonhart, and F. A. Spane, Jr. 1979. Hydrologic Studies Within the Columbia Plateau, Washington: An Integration of Current Knowledge. RHO-BWI-ST-5, Rockwell Hanford Operations, Richland, Washington.

Graham, D. L. 1983. Stable Isotopic Composition of Precipitation from the Rattlesnake Hills Area of South-Central Washington State. RHO-BWI-ST-44P, Rockwell Hanford Operations, Richland, Washington.

Graham, M. J., G. V. Last, and K. R. Fecht. 1984. An Assessment of Aquifer Intercommunication in the B Pond, Gable Mountain Pond Area. RHO-RE-ST-12P, Rockwell Hanford Operations, Richland, Washington.

Hartman M. J. and P. E. Dresel (eds.). 1997. Hanford Site Groundwater Monitoring for Fiscal Year 1996. PNNL-11470, Pacific Northwest National Laboratory, Richland, Washington.

IGW (Intercontractor Working Group). 1987. Data Compilation: Iodine-129 in Hanford Groundwater. WHC-EP-0037, Westinghouse Hanford Company, Richland, Washington.

Jensen, E. J. 1987. An Evaluation of Aquifer Intercommunication Between the Unconfined and Rattlesnake Ridge Aquifers on the Hanford Site. PNL-6313, Pacific Northwest Laboratory, Richland, Washington.

Liikala, T. L. 1994. Hydrogeology Along the Southern Boundary of the Hanford Site Between the Yakima and Columbia Rivers, Washington. PNL-10094, Pacific Northwest Laboratory, Richland, Washington.

Reidel, S. P., and K. R. Fecht. 1994. Geologic Map of the Richland 1:100,000 Quadrangle. Open File Report 94-8. Washington Division of Geology and Earth Resources, Olympia, Washington.

Spane, F. A., Jr., and R. G. Raymond. 1993. Preliminary Potentiometric Map and Flow Dynamic Characteristics for the Upper-Basalt-confined aquifer System. PNL-8869, Pacific Northwest Laboratory, Richland, Washington. 
Spane, F. A. Jr., and V. R. Vermeul. 1994. Summary and Evaluation of Hydraulic Property Data Available for the Hanford Site Upper Basalt-confined aquifer System. PNL-10158, Pacific Northwest Laboratory, Richland, Washington.

Spane, F. A. Jr., and W. D. Webber. 1995. Hydrochemistry and Hydrogeologic Conditions Within the Hanford Upper Basalt-confined aquifer System. PNL-10817, Pacific Northwest Laboratory, Richland, Washington.

Strait, S. R., and R. B. Mercer. 1987. Hydraulic Property Data from Selected Test Zones on the Hanford Site. SD-BWI-DP-051, Westinghouse Hanford Company, Richland, Washington.

Thorne, P. D., M. A. Chamness, F. A. Spane, V. R. Vermeul, and W. D. Webber. 1993. ThreeDimensional Conceptual Model for the Hanford Site Unconfined Aquifer System, FY93 Status Report. PNL-8971, Pacific Northwest Laboratory, Richland, Washington.

Whiteman, K. J. 1986. Ground-water Levels in Three Basalt Hydrologic Units Underlying The Columbia Plateau in Washington and Oregon, Spring 1984. Water-Resources Investigations Report 864046, 4 Sheets, U. S. Geological Survey, Washington, D.C.

Whiteman, K. J., J. J. Vaccaro, J. B. Gonthier, and H. H. Bauer. 1994. The Hydrogeologic Framework and Geochemistry of the Columbia Plateau Aquifer System, Washington, Oregon, and Idaho. Professional Paper 1413-B, U. S. Geological Survey, Washington, D.C.

Wurstner, S. K., P. D. Thorne, M. A. Chamness, M. D. Freshley, and M. D. Williams. 1995. Development of a Three-Dimensional Ground-Water Model of the Hanford Site Unconfined Aquifer System: FY 1995 Status Report. PNL-5506, Pacific Northwest Laboratory, Richland, Washington. 


\section{Distribution}

No. of

Copies

\section{OFFSITE}

Confederated Tribes of the

Umatilla Indian Reservation

Environmental Planning/Rights Protection

P.O. Box 638

Pendleton, OR 97801

ATTN: T. Gilmore

B. Drost

Geological Survey

U.S. Department of the Interior

1201 Pacific Avenue, Suite 600

Tacoma, WA 98402

D. Dunning

State of Oregon Department of Energy

625 Marion Street N.E.

Salem, OR 97310

W. Rigsbee

Yakama Indian Nation

Environmental Restoration/Waste

Management

P.O. Box 151

Toppenish, WA 98948

S. Sobczyk

Nez Perce Tribe

Environmental Restoration/Waste

Management

P.O. Box 365

Lapwai, ID 83540-0365
No. of

Copies

R.A. Danielson

State of Washington Department of Health 2 South 49th Avenue

Yakima, WA 98908

\section{ONSITE}

5 DOE Richland Operations Office
M. J. Furman
$\mathrm{HO}-12$
R. D. Hildebrand
$\mathrm{HO}-12$
K. M. Thompson
HO-12
Public Reading Room (2)
$\mathrm{H} 2-53$

2 Bechtel Hanford, Inc.
K. R. Fecht
H0-02
A. J. Knepp
HO-19

2 CH2M Hill Hanford, Inc.
J. V. Borghese
H9-03
L. C. Swanson
H9-02

3 State of Washington

Department of Ecology
S. M. Alexander
B5-18
L. Cusack
B5-18
S. Leja
B5-18

2 U.S. Environmental Protection Agency
L. E. Gadbois
B5-01
D. R. Sherwood
B5-01

Distr.1 
No. of

Copies

29 Pacific Northwest National Laboratory

D. B. Barnett

R. W. Bryce

P. E. Dresel

M. D. Freshley

M. J. Hartman

V. G. Johnson

J. W. Lindberg

S. P. Luttrell

D. R. Newcomer

S. P. Reidel

R. M. Smith

F. A. Spane, Jr.

P. D. Thome (8)

W. D. Webber

B. A. Williams

Information Release Office (7)
K6-81

K6-91

K6-96

K9-36

K6-96

K6-96

K6-81

K6-96

K6-96

K6-81

K6-96

K6-96

K9-33

K6-96

K6-81

K1-06

Distr.2 